\title{
Pyrolysis of Used Tires Using Spent Catalyst of Crude Oil Cracking Process from Pertamina RU III
}

\section{Pirolisis Limbah Ban Bekas Menggunakan Katalis Bekas Perengkahan Minyak Bumi Pertamina RU III}

\author{
Kiagus Ahmad Roni ${ }^{\text {a,1,* }}$, Muhammad Roy Tri Handono ${ }^{\mathrm{a}, 2}$, Zahrul Mufrodi ${ }^{\mathrm{b}, 3}$ \\ a Program Studi Teknik Kimia, Fakultas Teknik, Universitas Muhammadiyah Palembang \\ ${ }^{\mathrm{b}}$ Program Studi Teknik Kimia, Fakultas Teknologi Industri, Universitas Ahmad Dahlan, Yogyakarta \\ ${ }^{1}$ kiagusaroni@gmail.com*; ${ }^{2}$ muhammadroytrihandono@gmail.com; ${ }^{3}$ zahrul.mufrodi@che.uad.ac.id \\ * corresponding author
}

\section{ARTICLE INFO}

Article history

Received February 01, 2020

Revised February 25, 2020

Accepted June 18, 2020

\section{Keywords}

Pirolisis

Ban bekas

Polystirena

Katalis

\section{ABSTRACT}

The additional waste of used tires increases every year in direct proportion to the growth of motorized vehicles. Problems caused by used tire waste will also increase if there is no right solution to reduce waste. Catalytic pyrolysis is one way to change used tires into another form that has the benefit of liquid fuel. Polystyrene contained in used tires is a synthetic polymer that can be converted into liquid fuel by pyrolysis method. PT Pertamina RU III Palembang's former petroleum cracking catalyst can still be reused as a catalyst in the pyrolysis of used tires to improve the process by reducing cracking temperature and cracking time to obtain maximum liquid fuel. The process is carried out using 500 grams of used tire rubber with catalysts of $0 \%, 20 \%, 40 \%, 60 \%$, and $80 \%$ of the weight of used tire rubber with a heating time of 120 minutes and 180 minutes. Based on the results of the study, the highest volume of liquid fuel was produced from the addition of an $80 \%$ catalyst from the weight of the used tire rubber with a pyrolysis time of 180 minutes, $71 \mathrm{ml}$. The liquid fuel obtained is then analyzed using Gas Chromatography. From this analysis, the results obtained from the pyrolysis of used tire rubber using a catalyst used by PT Pertamina RU III Palembang used oil is approaching premium fuel. So it can be concluded that used rubber tires containing polystyrene can be processed into liquid fuels.

This is an open access article under the CC-BY-SA license.

\section{Pendahuluan}

Produksi kendaraan bermotor dunia, berdasarkan data kelompok penelitian karet internasional atau International Rubber Study Group (IRSG), mencapai 59.623.000 unit pada 2013, tumbuh 21\% dari produksi 2012 yang hanya 49.650 .000 unit. Tahun 2016, produksi otomotif global diperkirakan tetap naik 8,9\% atau sebanyak 64.033 .000 unit. Sepanjang 2014, produksi ban dunia diprediksi mencapai 1.151.836 unit, lebih besar 7,7\% dari produksi tahun lalu yang sebanyak 1.079.432 unit atau melonjak 13,8\% dari 2012. Dari pemakaian kendaraan bermotor tersebut salah satu komponennya yang pasti diperlukan adalah ban, baik ban mobil maupun ban sepeda motor. Bila Kendaraan tersebut dipakai maka dalam jarak kurang $2.500 \mathrm{KM}$ harus sudah diganti dengan ban yang baru, kemudian ban bekasnya dibuang. Seiring dengan itu, maka limbah ban-ban bekas yang tidak terpakai di lingkungan semakin meningkat [1]. 
Ban bekas yang yang terbuat dari karet yang dibuang tidak akan membusuk, memerlukan ruang yang luas untuk menampungnya dan apabila dibakar akan menyebabkan polusi. Hasil pembakaran yang sedikit banyak akan mempengaruhi pemanasan global yang semakin meningkat. Oleh karena itu, diperlukan usaha untuk mengubah limbah ban bekas menjadi sesuatu yang lebih berguna lagi, agar tidak mencemari lingkungan. Penanganan ban bekas tersebut biasa dilakukan dengan menggunakan cara yang sudah populer yaitu 3R (Reuse, Reduce, Recycle), akan tetapi cara itu mempunyai kelemahan. Alternatif yang lebih baik untuk menangani sampah atau limbah ban bekas adalah mengkonversi menjadi bentuk lain, yaitu bahan bakar cair sebagai energi alternatif [2].

Ban berbahan dasar karet adalah salah satu polimer sintetis (polystyrene) yang berasal dari minyak bumi. Sehingga solusi terbaik saat ini adalah mengembalikan ke bentuk minyak bumi. Perengkahan polystyrene adalah cara mengurangi limbah tersebut. Perengkahan (cracking) adalah proses memutus rantai polimer menjadi senyawa dengan berat molekul yang lebih rendah. Meskipun cara ini termasuk ke dalam recyle, tetapi hasil daur ulang bukan menjadikan kembali ke bentuk ban [3].

Perengkahan ban bekas ini menggunakan metode pirolisis. Pirolisis atau pirolisa adalah proses penguraian biomassa dengan memanfaatkan panas pada suhu $150{ }^{\circ} \mathrm{C}$. Pada proses ban bekas ini berlangsung pada suhu tinggi, sehingga diperlukan katalis untuk menurunkan temperatur dan mempercepat reaksi perengkahan. Selain dapat mempersingkat waktu proses juga bisa mendapatkan produk bahan bakar yang baik [4].

Berdasarkan permasalahan tersebut, maka perlu dilakukan penelitian untuk mengurangi limbah ban bekas sekaligus untuk menentukan pengaruh katalis yang digunakan dalam perengkahan. Pembuatan bahan bakar cair, dengan memanfaatkan limbah ban bekas menggunakan katalis bekas perengkahan minyak bumi Pertamina RU III Palembang. Dengan metode pirolisis menggunakan katalis bekas diharapkan bisa mengurangi limbah ban bekas dengan hasil konversi minyak yang lebih banyak dan berkualitas baik.

Pirolisis merupakan perengkahan (cracking) dengan bantuan panas dalam kondisi bebas atau sedikit oksigen, untuk mengurai senyawa organik dari suatu bahan padat menjadi produk cair dan gas dengan melepaskan ikatan bahan-bahan anorganik yang terikat. Proses pirolisis dapat disebut juga dengan proses perengkahan atau cracking. Cracking adalah proses pemecahan rantai polimer menjadi senyawa dengan berat molekul yang lebih rendah. Ada tiga macam proses cracking yaitu hidro cracking, thermal cracking, dan catalytic cracking [5]. Konversi limbah ban bekas menjadi bahan bakar memiliki beberapa keuntungan dan merupakan salah satu alternatif utama untuk pengolahan limbah ban bekas, karena metode landfill dan insenerasi memiliki berbagai dampak terhadap lingkungan seperti polusi udara serta pencemaran tanah. Dalam pirolisis, bahan polimer dipanaskan sampai suhu tinggi, sehingga struktur makromolekul mereka dipecah menjadi molekul yang lebih kecil, produk pirolisis dapat dibagi menjadi fraksi gas, fraksi cair yang terdiri dari parafin, olefin, naftena, aromatik, dan residu padat [6].

Pirolisis, disebut juga thermolisis (Yunani: pur = api, termos $=$ hangat; luo = melonggarkan), adalah proses dekomposisi kimia dan termal, umumnya mengarah ke molekul yang lebih kecil. Thermolisis adalah istilah yang lebih tepat daripada pirolisis karena api menunjukkan adanya oksigen. Sebagian besar proses pirolisis udara dihilangkan untuk alasan keamanan, kualitas produk, dan yield. Pirolisis dapat dilakukan pada berbagai suhu, waktu reaksi, tekanan, dan dengan adanya atau tidak adanya gas atau cairan, dan katalis reaktif. Pirolisis ban bekas dapat diproses pada suhu rendah $\left(150{ }^{\circ} \mathrm{C}\right)$, menengah $\left(150-600^{\circ} \mathrm{C}\right)$ atau suhu tinggi $\left(>600{ }^{\circ} \mathrm{C}\right)$ dan umumnya dilakukan pada tekanan atmosfer. Pirolisis selain dilakukan untuk ban bekas juga dilakukan untuk plastik [7-8].

Keuntungan dari proses pirolisis thermal cracking antara lain, volume sampah dapat berkurang secara signifikan yaitu kurang dari 50\% hingga 90\%, hasil yang berbentuk padat, cair, dan bahan bakar gas dapat diproduksi dari limbah, bahan bakar atau bahan kimia yang diperoleh dapat disimpan atau diangkut, masalah lingkungan berkurang, energi alternatif bersumber dari bahanbahan terbarukan seperti sampah kota, serta biaya modal rendah [9].

Dari proses thermal cracking akan dihasilkan arang, minyak dari kondensasi gas seperti parafin, isoparafin, olefin, naphthene, dan aromatik, serta gas yang memang tidak bisa terkondensasi. Sebagai aturan umum semakin tinggi suhu pirolisis, semakin tinggi hasil produk gas yang tidak dapat terkondensasi, dan menurunkan yield bahan bakar cair. 
Hydro cracking adalah proses cracking dengan mereaksikan bahan dengan hidrogen di dalam wadah tertutup yang dilengkapi dengan pengaduk pada temperatur antara $150-400{ }^{\circ} \mathrm{C}$ dan tekanan hidrogen 3-10 MPa. Dalam proses hydrocracking ini dibantu dengan katalis. Hydrocracking sampah polimer biasanya melibatkan reaksi dengan hidrogen katalis yang berlebih dalam autoclave batch yang diaduk pada suhu tinggi dan bertekanan. Pekerjaan tersebut, terutama berfokus untuk memperoleh kualitas bensin tinggi mulai dari berbagai feed. Feed khas termasuk polietilena, polietilena tereftalat, polistirena, polivinil klorida, dan polimer campuran, polimer limbah dari sampah kota dan sumber-sumber lain telah dievaluasi dan termasuk logam transisi (misalnya, $\mathrm{Pt}, \mathrm{Ni}$, $\mathrm{Mo}, \mathrm{Fe}$ ) didukung oleh padatan asam (seperti alumina, amorf silika-alumina, zeolite, dan zirkonia sulfat). Katalis ini menggabungkan kedua kegiatan hidrogenasi dan cracking [10].

Catalytic cracking merupakan proses cracking yang menggunakan katalis untuk melakukan reaksi perengkahan, dimana dengan adanya katalis dapat mengurangi temperatur dan waktu reaksi. Hasil proses pada hidrokarbon ringan yang terjadi pada suhu yang lebih rendah. Biaya harus dikurangi untuk membuat proses lebih menarik dari perspektif ekonomi. Penggunaan kembali katalis dan penggunaan katalis yang efektif dalam jumlah yang lebih kecil dapat mengoptimalkan pilihan ini. Proses ini dapat dikembangkan dengan biaya yang efisien dengan menggunakan proses daur ulang polimer komersial untuk memecahkan masalah lingkungan dari pembuangan limbah ban bekas. Daur ulang katalitik telah terbukti secara signifikan lebih efisien daripada thermal craking. Variabel-variabel utama dalam proses perengkahan katalis adalah suhu dan tekanan. Kenaikan konversi reaksi dapat dicapai dengan cara menaikkan suhu dan tekanan.

Degradasi ban bekas mengarah pada pembentukan gas, cairan, dan residu. Dalam degradasi polistirena, coke juga dibentuk. Katalis heterogen lebih mudah terpisah dari medium reaksi namun katalis ini kesulitan dalam deaktifasi karena dapat menjadi coke, sedangkan katalis homogen sulit untuk di keluarkan dari produk akhir dan akibatnya katalis tersebut lebih mudah menjadi lumpur. Efek utama penambahan katalis dalam pirolisis ban bekas yaitu, suhu pirolisis untuk mencapai konversi tertentu berkurang drastis dan sebagai rasio katalis atau ban meningkat, suhu pirolisis dapat lebih diturunkan. Lebih banyak iso-alkana dan aromatik di kisaran $\mathrm{C}_{5}-\mathrm{C}_{18}$ dapat di produksi, yang sangat diinginkan bensin-rentang hidrokarbon. Laju reaksi meningkat secara signifikan, dua hingga empat kali lebih cepat dari pada noncatalytic thermal cracking [10].

\section{Metodologi Penelitian}

Bahan baku yang digunakan merupakan ban bekas dari kendaraan roda dua. Ban bekas yang digunakan mengandung polistirena yang dikumpulkan dari bengkel motor dan tambal ban yang ada di sekitar daerah plaju Palembang. Karet ban bekas dipotong menjadi ukuran 0,5 cm. Lalu ditimbang dan dipisahkan dengan berat 500 gram. Katalis yang digunakan pada penelitian ini adalah limbah bekas perengkahan minyak bumi PT Pertamina RU III Palembang dan mengajukan permohonan permintaan katalis tersebut pada Pertamina RU III sebanyak $2 \mathrm{~kg}$. Setelah katalis didapat maka langsung dipisahkan dan ditimbang sesuai berat variabel penelitian yakni $0 \%, 20 \%$, $40 \%, 60 \%$, dan $80 \%$.

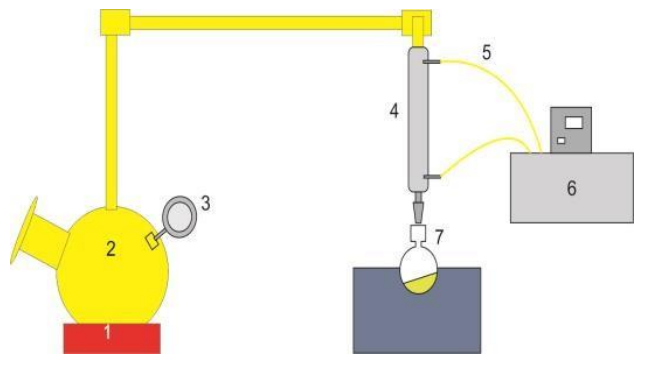

Keterangan:

1.Pemanas; 2.Tabung pirolisis; 3.Termometer gas; 4.Kondensor; 5.Selang; 6.Water bath; 7.Penampung kondensat

Gambar 1. Skema Alat Proses Pirolisis. 
Pirolisis dilakukan dengan cara memanaskan tabung pirolisis pada kondisi operasi $200{ }^{\circ} \mathrm{C}$ dengan tekanan $1 \mathrm{~atm}$, yang telah berisi campuran karet ban bekas dan katalis sesuai variabel penelitian, dengan pemanas sampai suhu yang telah ditentukan. Rangkaian alat pirolisis disajikan pada Gambar 1. Uap yang dihasilkan dari pirolisis dialirkan yang kemudian dikondensasi oleh kodensor lalu di tampung pada tabung kondensat. Setelah hasil kondensat didapat hasil lalu didestilasi dan hasilnya langsung dianalisa menggunakan gas chromatograhy. Variabel waktu yang digunakan adalah 120 menit dan 180 menit.

\section{Hasil dan Pembahasan}

Hasil pirolisis berupa bahan bakar cair yang didapat dengan menggunakan katalis sebanyak 100, 200, 300, dan 400 gram pada suhu 120 dan 180 menit dapat dilihat pada Gambar 2. Dari Gambar 2 dapat dilihat hubungan antara berat katalis yang digunakan dengan hasil bahan bakar cair pada variabel waktu yang telah ditentukan. Terhadap hasil bahan bakar cair pada waktu 120 menit dan 180 menit, bahwa volume hasil bahan bakar cair terus meningkat bersamaan dengan meningkatnya jumlah berat katalis yang ditambahkan. Ini dapat dilihat pada Gambar 2 dan 3 baik dalam waktu 120 menit atau 180 menit.

Penambahan katalis yang digunakan pada perlakuan variabel waktu 120 menit dan 180 menit mulai dari $0 \%, 20 \%, 40 \%, 60 \%$, dan $80 \%$ dari berat ban bekas yaitu tanpa katalis, penambahan 100 , 200, 300, dan 400 gram berat katalis yang ditambahkan pada proses pirolisis yang dilakukan dan menunjukan pula peningkatan seperti pada gambar yang disajikan. Volume tertinggi yang dapat dihasilkan dari proses pirolisis karet ban bekas pada waktu pirolisis 180 menit yaitu sebanyak $71 \mathrm{ml}$ dengan penambahan berat katalis yang digunakan sebanyak 400 gram. Dari data yang ada dapat dibuat persamaan matematis yang mendekati hasil proses yaitu $\mathrm{y}=0,057 \mathrm{x}+33,4$ untuk 120 menit dan $\mathrm{y}=0,084 \mathrm{x}+37,2$ untuk 180 menit. Sedangkan persen hasil bahan bakar cair karena penambahan katalis jika dibandingkan tanpa katalis dapat dilihat pada Gambar 3.

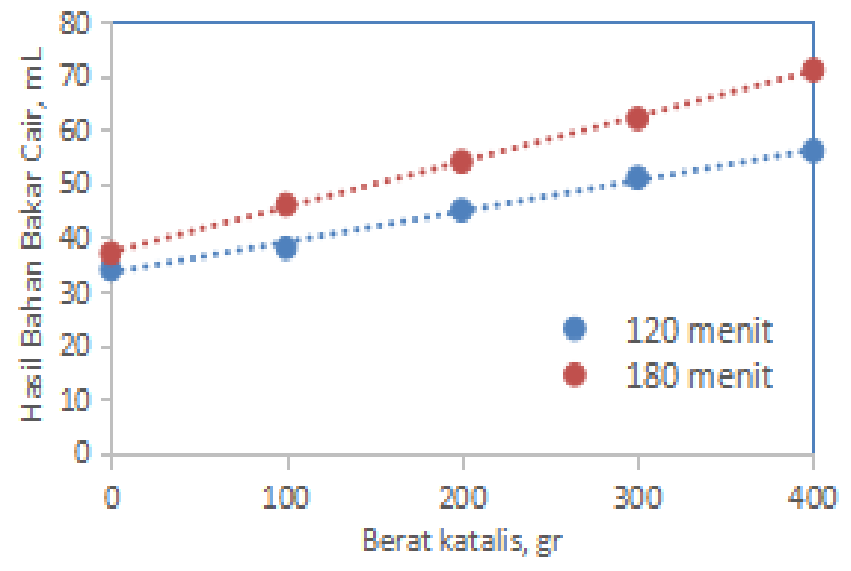

Gambar 2. Hasil pirolisis pada berbagai berat katalis dalam waktu 120 dan 180 menit.

Dari Gambar 3 dapat dilihat bahwa penambahan katalis mengakibatkan persen penambahan hasil semakin meningkat. Peningkatan tertinggi mencapai 64,71\% dalam waktu 120 menit dan 91,89\% untuk waktu 180 menit. Jadi, memperpanjang waktu pirolisis dapat memperoleh hasil bahan bakar cair yang lebih banyak. Hal ini dikarenakan perengkahan dari karet ban bekas untuk memecah rantai lebih banyak karena meningkatnya waktu pirolisis sehingga volume bahan bakar cair yang didapat semakin banyak. Dengan meningkatnya suhu maka semakin banyak ikatan polimer yang terputus dan membentuk rantai pendek [11].

Dari hasil proses pirolisis ban bekas yang dilakukan, pada variabel berat katalis dan waktu pirolisis, diperoleh hasil berupa produk bahan bakar cair yang kemudian dianalisa secara kualitatif. Dengan menggunakan gas kromatografi dilakukan di Pertamina RU III Palembang. Dimana hasil dari analisa tersebut langsung dibandingkan dengan bahan bakar cair dari pertamina seperti premium, minyak tanah, dan solar. Densitas bahan bakar cair hasil dari penelitian yang dilakukan termasuk ke dalam batas densitas premium, meskipun nilainya mendekati batas densitas maksimum dari premium. Titik nyala bahan bakar cair hasil penelitian berada di bawah batas minimum flash 
point dari premium, tetapi jika dibandingkan dengan minyak tanah maka titik nyalanya berada diatas batas minimum titik nyala dari minyak tanah.

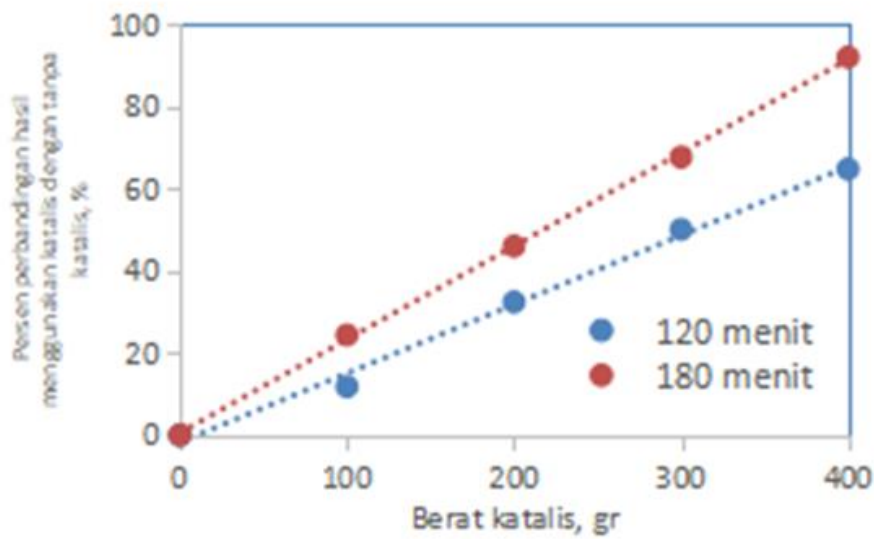

Gambar 3. Rasio pirolisis dengan dan tanpa penggunaan katalis dalam waktu 120 dan 180 menit.

Tabel 1. Perbandingan Bahan Bakar Cair Hasil Penelitian dengan Bahan Bakar Cair Pertamina

\begin{tabular}{|c|c|c|c|c|c|c|c|c|}
\hline \multirow{2}{*}{$\begin{array}{c}\text { Karakteristik } \\
\text { (Parameter) }\end{array}$} & \multirow[t]{2}{*}{ Unit } & \multirow{2}{*}{$\begin{array}{c}\text { Hasil } \\
\text { Penelitian }\end{array}$} & \multicolumn{2}{|c|}{ Premium } & \multicolumn{2}{|c|}{$\begin{array}{c}\text { Minyak } \\
\text { Tanah }\end{array}$} & \multicolumn{2}{|c|}{ Solar } \\
\hline & & & $\min$ & $\max$ & $\min$ & $\max$ & $\min$ & $\max$ \\
\hline Density $\left(15^{\circ} \mathrm{C}\right)$ & $\mathrm{Kg} / \mathrm{m}^{3}$ & 778 & 715 & 780 & 775 & 840 & 815 & 870 \\
\hline Flash Point & ${ }^{\circ} \mathrm{C}$ & 27 & -36 & - & 38 & - & 52 & - \\
\hline Sulfur Content & $\%$ & 0,13 & - & 0,05 & - & 0,2 & - & 0,50 \\
\hline
\end{tabular}

Sedangkan, pada kandungan sulfur yang dimiliki bahan bakar cair jika dibandingkan dengan minyak tanah dan solar kandungan sulfurnya lebih sedikit, dan lebih banyak dari premium. Sampel yang diperoleh dari penelitian pembuatan bahan bakar cair dengan memanfaatkan limbah ban bekas menggunakan katalis dari limbah bekas perengkahan minyak bumi Pertamina RU III Palembang. Dengan metode pirolisis ini menghasilkan minyak yang hampir setara premium. Dari hasil penelitian, diperoleh juga bahwa pada suhu yang tetap dan berat atau jumlah katalis yang semakin besar, bahan bakar cair yang dihasilkan pun semakin banyak. Hal ini dikarenakan semakin banyak gugus asam yang berasal dari katalis maka reaksi dekomposisi karet ban bekas menjadi senyawa yang lebih sederhana akan semakin baik.

\section{Kesimpulan}

Berdasarkan hasil penelitian dengan penambahan katalis 0 sampai 400 gram dan waktu 120 dan 180 menit dapat disimpulkan bahwa semakin banyak katalis yang digunakan dan waktu pirolisis yang lebih lama akan menghasilkan bahan bakar cair yang lebih banyak. Hasil Bahan Bakar Cair terbanyak yang telah didapatkan dari proses pirolisis adalah $71 \mathrm{ml}$ pada penggunaan katalis $400 \mathrm{gr}$ dan waktu pirolisis 180 menit. Bahan bakar cair yang didapatkan dari hasil proses pirolisis pada penelitian ini adalah hampir setara dengan premium.

\section{Daftar Pustaka}

[1] Mutho dan Efendri, E., Pemanfaatan Limbah Padat Pabrik Crumb Rubber (Tatal) Pada Pembuatan Bahan Bakar Cair. Palembang: Baristand, 2013.

[2] APBI. Laporan Asosiasi Perusahaan Ban Indonesia. Jakarta, 2017.

[3] Bahri, S., Pemanfaatan Limbah Padat Pabrik Crumb Rubber (Tatal) Pada Pembuatan Bahan Bakar air, Palembang:Baristand, 2013.

[4] Damayanthi, Reska, dan Martini, Retno. 2009. "Proses Pembuatan Bahan Bakar Cair dengan memanfaatkan Limbah Ban Bekas menggunakan Katalis Zeolit HY dan ZSM-5," Jurnal Teknik Kimia Universitas Diponegoro, Semarang, 2009. 
[5] Pratiwi, A. Pembuatan Bahan Bakar Cair Dari Limbah Plastik Menggunakan Metode Thermal Cracking.Palembang: Polsri, 2010.

[6] Purwanti A. Kinetika Reaksi Thermal Cracking Plastik Low Density Poliethylene (LDPE).Yogyakarta. 2008.

[7] Syamsiro, M., Saptoadi, H., Kismurtono, M., Mufrodi, Z., dan Yoshikawa, K. "Utilization of waste polyethylene pyrolysis oil as partial substitute for diesel fuel in a DI diesel engine", International Journal of Smart Grid and Clean Energy, 8(1) 38-47, 2019.

[8] Syamsiro, M, Mufrodi, Z., Rafly R., dan Machmud, S., "Energy Recovery from Food Packaging Plastic by Thermal and Catalytic Pyrolysis Processes", Universal Journal of Mechanical Engineering, 8(1) : 51$58,2020$.

[9] Wojtowicz, M . A and M . A Serio. "Pyrolysis of Scrap Tires : Can it be Profitable," Chemtech, October 1996. pp 48- 53

[10] Sabarodin, A,. "Pembuatan Minyak Bakar Dari Sampah Plastik Sebagai Sumber Energi Alternatif," Yogyakarta, 1998.

[11] Ismi, L., Susilo, B., dan Yulianingsih, R., "Studi Pemanfaatan Minyak Karet (Havea brasiliensis) sebagai bahan bakar rumah tangga,” Jurnal Kteknikan Pertanian Universitas Brawijaya, Malang, 2013. 